\title{
The effectiveness of MALL and flipped classroom in teaching writing to the eleventh graders of SMA in Banyumas
}

\author{
Benny Krisbiantoro*, Tri Pujiani \\ English Education Department, Universitas Harapan Bangsa, Indonesia \\ *Corresponding Author \\ Email: bennykrisbiantoro@uhb.ac.id
}

Received:

21 November 2020
Revised:

11 January 2021
Accepted:

27 February 2021
Published:

28 February 2021

\begin{abstract}
MALL has become an invaluable means in teaching writing for learners in and out of the classroom. Although there were many researches on MALL to enhance writing competence, analytical exposition text writing was never carried out. This study was aimed to investigate whether: (1) MALL was more effective than Flipped classroom to teach writing for the eleventh graders of SMA (senior high school); (2) the high creative students possessed better writing skills than the low creative ones; and (3) an interaction effect occurred between the methods of teaching and creativity to teach writing for the eleventh graders of SMA in Banyumas. The employed method was an experimental research with factorial design. The population of the research was the eleventh graders of SMA in Banyumas. Four schools were purposively taken. There were two samples in this research; experimental class comprising 72 students from SMAN 01 Banyumas and SMAN 01 Baturraden and control class containing 72 students from SMAN 03 Purwokerto and SMAN 01 Sokaraja. The occupied instruments in this research were verbal creativity and writing test. The data analyses were in the matter of frequency distribution, normality, homogeneity, ANOVA and TUKEY. The results of the study revealed that: (1) MALL is more effective than Flipped classroom in teaching writing for the eleventh graders of SMA; (2) the high creative students possessed better writing competence than the low creative students; and (3) an interaction effect happened between the methods of teaching and creativity in regards to writing teaching.
\end{abstract}

Keywords: MALL; Flipped classroom; creativity; writing

\section{INTRODUCTION}

Technology has passed through all aspects of our lives and widened the space of educational practice by providing innovative and smart devices, wireless broad-band technology, and innovative application services (Çakmak, 2019). With the use of technology, every human being is capable of reaching the unreached and untouched whenever and wherever they are without being hampered by time and space constraints (Gangaiamaran \& Pasupathi, 2017). One of the outstanding innovations created by the mankind in history is mobile phones. Mobile phones grow and spread very swiftly over the globe with 
new features and improvement every time. In learning, the utilization of mobile phones is undoubtedly as well as inevitably believed to enhance the performance of the students as well as the teachers in or out of the classrooms.

Kukulska-Hulme and Shield (2007) stated that mobile learning is growing very swiftly time to time. Early mobile learning projects are developed carefully for purposeful activities by teachers and technicians, and new technologies that are not easy to master or implement. Mobile-assisted language learning (MALL) is a method commonly used and considered one of the skills of the 21 st century. New teaching methods using the latest technology are needed, making the latest literature flooded with research on how effective MALL is to the teaching of English. Using MALL to encourage the learning of English language can reduce boredom and time and space constraints that traditional teaching methods usually cause. Since all people around the world use technology massively, it is necessary to use this tool for teaching and learning process instead of limiting it to unproductive activities (Gangaiamaran \& Pasupathi, 2017; Wahyuni, et al., 2019; Shadiev, et al., 2020).

\section{Mobile Assisted Language Learning (MALL)}

MALL is a teaching method that uses a cell phone or other wireless and portable palm-hand tools, like telephones, tablets, and PDAs (Khubyari \& Narafshan, 2016). MALL, according to Burston (2013), focuses on using specific features such as digital dictionaries, mobiles, music players, and the latest sophisticated and user-friendly computers. MALL is one of the latest technological developments and as a transformation of CALL which has specialty on its mobility, connectivity and affordability (Alotumi, 2019). Rohandi, et al. (2017) stated that MALL is part of e-learning which involves the application of cellular technology in language learning. MALL is a method that employs mobile technology to emphasize the centrality and autonomy of learners (Alemi, et al., 2012). Geddes (2004, as cited in Alemi et al., 2012) defined MALL as the type of learning that occurs anytime and anywhere, namely making the process of delivering the materials to the students undertaken outside the classroom so that the students can be autonomous for their self-study. Rahamat (2019) stated that mobile learning can be integrated with the learning carried out by the students and the teachers and it is believed to be an option to enhance the students' interest and motivation. MALL is also defined as the way people use mobile devices to learn languages through wireless technology and wireless communication, because through this method, users can get content or information from all over the world, which is very useful for enhancing abilities (Vemula, 2018). According to Baleghizadeh \& Oladrostam (2010), MALL is a branch of technology-enhanced learning which might be enforced in varied forms as well as face-to face, distant or on-line modes. Burston (2014) defined MALL as a method which promotes the use of any kind of flexible and accessible tools to the language learning.

Based on the definitions of MALL mentioned previously, it can be inferred that MALL is the teaching and learning method which can enable the students to learn language anytime and anywhere and it allows them to learn the 
Krisbiantoro, B., \& Pujiani, T. (2021). The effectiveness of MALL and flipped classroom

language autonomously, flexibly and responsibly with the help of a handheld mobile technology.

Cheng, et al. (2010) carried out a study about the influence of mobile phone and online system on the teaching of English in a higher educational institution. The findings revealed that there was a significant effect of the utilization of StudentPartner on English learning activities. However, there were only few participants in this study as well as its restriction on only the students as the direction, not on the other directions such as teachers and materials. Alemi et al. (2012) carried out a research about the utilization of MALL on academic vocabulary learning and retention to Iranian university students. The results revealed that the teachers could occupy SMS as a meaningful means to assist their pupils to hold vocabularies for a long time. Although their research findings showed that using SMS as part of mobileassisted language learning was useful, there was a limitation and weakness in their research. The participants in their study were in unequal number (28 in experimental group and 17 in control group). Besides, their research findings revealed that there was an improvement in the post test conducted by both groups and there was not any substantial difference among the groups.

Kalati (2013) held a research on mobile-assisted language learning and the research was aimed to investigate whether Iranian undergrad pupils agreed to employ mobile phones to both learn language skills and components. Based on the findings, there was $72 \%$ of the pupils liked to use mobile phones better in order to study English and 64\% of the pupils occupied an installed application to enhance their vocabulary mastery. There was also students' interest in utilizing sophisticated and advanced technology anywhere and there was a high consciousness that English was very vital for their future. The research, on the other hand, took only small sample size consisting of 36 men and women that were randomly selected. Besides, the focus of the study was restricted merely on enhancing vocabulary mastery using mobile devices. Unfortunately, the research did not mention what type of mobile application used in the study, yet it was all about mobile devices use in general. Khubyari and Narafshan (2016) carried out a study on the effect of MALL on students' reading comprehension. The results showed that the students really liked to read comprehensively using their mobile device because of its accessibility and portability. The study sample size which contained only 40 students was small and the focus was only on reading comprehension as well as the unclear type of mobile learning used in that study.

Another research conducted by Shi, et al. (2017) on the utilization of an Instant Messaging called WeChat. The findings revealed that students in the WeChat group significantly improved in English proficiency. In spite of the promising findings, the literature of their research does not have any study at all that investigated the function of WeChat as a tool in studying vocabulary and language skills. Firipis, et al. (2018) undertook a research on how influential critical thinking on creativity when using MALL. The findings of the research revealed that critical thinking gave an influence on creativity during MALL process. On the other hand, this study focused only on the description of how the critical thinking influenced the creativity in a mobile device assisted learning. This study did not explicitly explain how to apply MALL in improving 
students' decisive skills. Shamsi, et al. (2019) carried out a study on how to reduce anxiety using MALL and the result was that there was a substantial reduction on the learners' anxiety in speaking English. However, the study took a small sample size containing nine participants ( 6 females and 3 males) which could give an impact on the findings.

Gonulal (2019) conducted a study about the application of one of MALL tools; Instagram. The findings revealed that there was an improvement of students' language skills and components. The shortcomings of his research are firstly dealing with the sample size was not large enough, secondly there was only one type of social networking platforms that was examined, and thirdly about the use of a brief questionnaire to collect the data. Li and Cummins (2019) conducted a study on how influential texting is to improve students' vocabulary. The study showed that there was a significant effect of texting on students' words possession, nevertheless there was no difference on academic vocabulary mastery in both groups. In spite of the convincing findings, the research did not provide calculation of students' word on postponed final test. The length of the research was very short to deal with a sufficient number of unfamiliar words that would have allowed the pupils to acquire new academic words.

Gharehblagh and Nasri (2020) carried out a research on occupying MALL to develop students' writing competencies. Their research results showed that there was a significant advance on students' post-test writing; nevertheless, experimental group had better writing competencies than control group. Their research, however, only focuses on the Iranian students with elementary level of writing skills. Besides, the limitations of their research are on the length of the study and the inadequacy of data collection instruments. There were only nine sessions to work on elementary students' writing skills. In collecting the data quantitatively, they utilized essay scores and interviews. Meanwhile, in gathering the data qualitatively, they only employed interviews.

\section{Flipped classroom}

Chen, et al. (2017, as cited in Rodríguez, et al., 2019) defined flipped classroom as a dynamic instructing method which promotes higher-order thinking and active involvement and interaction from students. Hamdan, et al. (2013) pointed out that flipped classroom is a teaching method that transfers direct instruction from a group study room to a single study room, and then transforms the formed group space into an interactive learning environment where educators can learn. Brame (2012) defined flipped classroom as an instructional method, in which the learners get contact learning before class, and then concentrate on the process or advanced learning (synthesis, analysis and problem problems) in class. When the students have completed homework and class activities, students will receive feedback from the teacher in class.

Flipped classroom is defined as a student-focused situation which focuses on student learning experiences rather than classroom teaching. Teacher, in the conventional classroom setting, becomes the information giver as well as the stage wiser. Reverse learning can promote learning increase (Jarvis \& Halvorson, 2014). Brame (2012) stated that flipped classroom is meant that through readings or lectures and video presentations, students can relate to new material outside of the classroom. Anwar (2017) claimed that 
Krisbiantoro, B., \& Pujiani, T. (2021). The effectiveness of MALL and flipped classroom

flipped classroom is an instructional strategy in which the teachers have to maximize their efforts as well as creativity in order to create a successful learning besides the existence of supporting devices and tools. This indicates that the implementation of flipped classroom in the teaching and learning process requires the teachers' high devotion resulting in the delivery and the mastery of the learned lessons are prominently achieved.

Based on the definitions of flipped classroom mentioned above, flipped classroom is a learning method which promotes an independent learning undertaken by students followed by in-class activities in order to review, practice and give feedbacks of what the students have done before. The researchers also presented several studies that are relevant to the issue of using the Flipped classroom. Shimamoto (2012) showed that flipped classrooms have the opportunity to trigger a significant shift in the teaching methods used. With the assistance of technology, currently an educator is capable of providing a solution of conventional teaching methods by implementing combined learning methods which mix the advantages of straight teaching and dynamic learning in order to get pupils involved in the process of learning. Tirtasanjaya, et al. (2012 as cited in Krisbiantoro \& Pujiani, 2019) revealed that the application of the flipped classroom method is very beneficial for the next times. A likely enhancement is to include a variety of led inquiries occupied in the Bloom's taxonomy lowest level for autonomous activities and those in the highest level for activities done in the classroom.

Roehl, et al. (2013) conducted a research on the use of flipped classroom to engage millennial students through active learning strategies and revealed that in order to introduce several new strategies which are transferred from the teacher and the students' thoughts, the teacher has to carry out a research with an alternative strategy in the class. As the instructor that will use the new strategy, flipped classroom is very important in education reflected in an effective learning. By using active learning and flipped classroom learning strategy enriched with technology, the students will develop their creative thinking skill be higher. Another research by Mok (2014) yielded that having been implemented flipped classroom, the students were more involved and encouraged to be more responsible and autonomous in their learning. Smith (2015) undertook a research on the efficacy of flipped classroom and showed that there was not any improvement on learners' accomplishment in regards to flipped classroom, while it was stated that flipped classroom enabled the learners to get involved actively in the learning. Egbert, et al. (2015) showed that flipped instruction in English language teacher education was not appropriate for learners as well as for educators' pedagogical course. However, flipped classroom is considered successful relies on the students' position in the course, former knowledge, and the process of the FL itself. Abdelrahman, et al. (2017) conducted a research and proved that there was improvement regarding writing competence and satisfaction of the students based on their involvement and reciprocal actions with the developed book of paragraph writing.

In the research on the use of the flipped classroom mentioned above, there are still shortcomings or limitations. The first research is research conducted by Shimamoto (2012) which only focuses on using the flipped classroom as an alternative to traditional-based learning models. The second 
research is research carried out by Tirtasanjaya, et al. (2012) that only focused on variations in the guided question on $\mathrm{FC}$ at the lowest and highest degree of the taxonomy of Bloom The third is research by Roehl et al. (2013) which only focuses on developing students' creative thinking. The fourth is by Mok (2014) which was mainly concerned with an experimentation of the flipped classroom for a class of programming in which dynamic learning activity done by couple programming. The fifth is by Smith (2015) which employed a mixed-method research design to investigate student accomplishment and task submission among learners in flipped classroom and those in the conventional class. The sixth is by Egbert et al. (2015) which merely focuses on the exploration of FL of educators' pedagogical course for thought teachers using design-based research approach. The last is research conducted by Abdelrahman et al. (2017) which only focuses on enhancing writing using FL in one school in Sudan and the utilization of the module of paragraph writing and how the students' writing proficiency and satisfaction on the module.

\section{Teaching writing analytical exposition text using MALL}

In this study, MALL was used to teach writing in experimental class. In MALL, the teacher utilizes mobile applications as the tool for carrying out the teaching and learning process. In this study, the researchers employed Nearpod and Line application in teaching an analytical exposition text to the eleventh graders of XI IPS 2 (Social Science Class) of SMAN 01 Baturraden and XI IPA 4 (Natural Science Class) of SMAN 01 Banyumas. There were seventh meetings to implement MALL in these classes. The steps of teaching writing analytical exposition text using MALL are introducing the mobile device applications (Nearpod and Line), eliciting students' prior knowledge using some pictures that are relevant to the topics, asking the students to work in groups and find information related to the topics and share it with their group members, asking them to write an analytical exposition text, asking them to give peer feedback, giving them correction and feedback, and having them revise their writing.

\section{Teaching writing analytical exposition text using flipped classroom}

In this study, flipped classroom was employed to teach writing in control class. The authors implemented flipped classroom in teaching writing for the eleventh graders of XI IPS 3 (Social Science Class) of SMAN 03 Purwokerto and XI IPA 4 (Natural Science Class) of SMAN 01 Sokaraja (Senior High Schools) for seven meetings. The steps of teaching writing analytical exposition text using flipped classroom are independent work (at home activities/homework such as watching lecture video and reading materials about analytical exposition text writing) and in-class activities such as review, practices, solution-based activities, cooperating and producing.

The aims of this research were to investigate whether (1) in the teaching of writing, MALL was more effective than flipped classroom; (2) the high creative eleventh graders possessed writing competence better than the low creative students; and (3) an interaction effect occurred between the methods of teaching and creativity to teach writing to the eleventh graders in Banyumas senior high schools. 
Krisbiantoro, B., \& Pujiani, T. (2021). The effectiveness of MALL and flipped classroom

\section{METHODS}

The method employed in this study was an experimental method with a factorial design $2 \times 2$ which was to know the effects of independent variables towards dependent variable. In this study, the researcher utilized purposive sampling to determine the samples. As the samples in this study, there were 36 students of XI IPS 2 of SMAN 1 Baturraden, and 36 students of XI IPA 4 of SMAN 1 Banyumas as the experiment group in which MALL was occupied, while the control group in which flipped classroom was used comprised 36 students of XI IPS 3 of SMAN 3 Purwokerto and 36 students of XI IPA 4 of SMAN 1 Sokaraja. The total samples in this study were 144 students from four senior high schools. Having given verbal creativity test to the students and having analyzed the scores based on the median, the researchers determined that there were 72 students categorized high level of creativity (36 students from experimental class and another 36 from control class) and another 72 students was categorized having low level of creativity (36 students from experimental class and another 36 from control class).

In this study, writing skill was as the dependent variable was and learning models and creativity as the independent variables. In collecting the data, the researchers utilized a writing test (writing an analytical exposition text) given after the treatment was accomplished and a verbal creativity test given before the treatments commenced. According to Munandar (1988a), the aspects of the verbal creativity test were fluency, flexibility, originality, elaboration and redefinition. Fluency of thinking describes the number of ideas comes out from one's mind. Flexibility is described as the ability to use various approaches in solving problems. Originality is described as the one's ability to bring about original ideas. Elaboration is the ability to develop ideas and break them down in detail. Redefinition is the ability to give new definition of the ideas. Later, Munandar used those five aspects to create test for verbal creativity. The indicators of the creativity test were that: 1) the students are able to create some words based on the beginning of words given; 2) create some words based on the letters provided in one word; 3) construct sentences that have three words based on three letters provided; 4) find out the object of the two same characteristics; 5) find out unusual usages of the daily objects or things; and 6) find out or predicting the effects of an event. In determining the level of the students' creativity. In this research, the researchers utilized the measurement scale for the verbal creativity in the form of interval scale which was later converted into ordinal scale with two categories: high and low. It would be considered high if the score of creativity test was higher than the median (the midpoint of the score), while it would be categorized low if the score of the creativity test was lower than the median. The researchers used median to determine the level of students' creativity because median is said to be the appropriate measure of central tendency when the set of scores is not evenly distributed (Sprinthall, 2014)

The data were analyzed using (1) descriptive statistics; (2) normality and homogeneity; (3) ANOVA; (4) TUKEY; and (5) Statistical Hypothesis. 


\section{RESULTS AND DISCUSSION \\ Data description}

This study was an experimental design with a factorial design by which the researchers did not give a pre-test before conducting the treatment. The researchers only gave the post-test of writing an analytical exposition text to the experimental class (taught using MALL) and the control class (taught using flipped classroom). After the writing scores were gained, they were then sorted in accordance with students' creativity levels. The data description in this research is divided into eight parts that are described below.

\section{The score of students' writing taught using MALL}

The writing scores of the students who are taught using MALL are shown in the table 1 .

Table 1 . The scores of students' writing taught using MALL

\begin{tabular}{lllllll}
\hline N & Mean & Mode & Median & $\begin{array}{l}\text { Standard } \\
\text { Deviation }\end{array}$ & Highest & Lowest \\
\hline 72 & 75.67 & 74.5 & 75 & 2.2 & 82 & 72 \\
\hline
\end{tabular}

From table 1, the students' writing mean score was 75.67 , median 75 , mode 74.5 and standard deviation 2.2 .

\section{The score of students' writing taught using flipped classroom}

The writing scores of the students who are taught using Flipped classroom are seen in the table 2.

Table 2. The scores of students' writing taught using MALL

\begin{tabular}{lllllll}
\hline N & Mean & Mode & Median & $\begin{array}{l}\text { Standard } \\
\text { Deviation }\end{array}$ & Highest & Lowest \\
\hline 72 & 58.52 & 62.5 & 60.75 & 9.5 & 78 & 34.5 \\
\hline
\end{tabular}

From table 2 , the students' writing mean score was 58.52 , median 60.75 , mode 62.5 and standard deviation 9.5.

The writing scores of the high creative students in experimental and control class

The scores of writing of the high creative students are figured out in table 3.

Table 3. The scores of writing of the high creative students

\begin{tabular}{lllllll}
\hline N & Mean & Mode & Median & $\begin{array}{l}\text { Standard } \\
\text { Deviation }\end{array}$ & Highest & Lowest \\
\hline 72 & 66.73 & 74.5 & 72.25 & 11.1 & 82 & 35 \\
\hline
\end{tabular}

As described in the table 3 , the average score of writing of the high creative students is $66.73,72.25$ for the median, 74.5 for the mode, and 11.1 for the standard deviation.

The writing scores of the low creative students in experimental and control class

The scores of writing of the low creative students are depicted in table 4. 
Krisbiantoro, B., \& Pujiani, T. (2021). The effectiveness of MALL and flipped classroom in teaching writing to the eleventh graders of SMA in Banyumas. EduLite: Journal of English Education, Literature, and Culture, 6 (1), 86-104. http://dx.doi.org/10.30659/e.6.1.86-104

Table 4. The scores of writing of the low creative students

\begin{tabular}{lllllll}
$\mathbf{N}$ & Mean & Mode & Median & $\begin{array}{l}\text { Standard } \\
\text { Deviation }\end{array}$ & Highest & Lowest \\
\hline 72 & 67.46 & 73.5 & 73.5 & 11 & 82 & 34.5 \\
\hline
\end{tabular}

As presented in the table 4, the average score of the low creative students' writing is $67.46,73.5$ for the median, 73.5 for the mode, and 11 for the standard deviation.

The writing scores of the high creative students in experimental class

The scores of the high creative students' writing in experimental class can be seen in table 5 .

Table 5. The scores of the high creative students' writing in experimental class

\begin{tabular}{lllllll} 
N & Mean & Mode & Median & $\begin{array}{l}\text { Standard } \\
\text { Deviation }\end{array}$ & Highest & Lowest \\
\hline 36 & 75.45 & 74.5 & 75 & 2.2 & 82 & 72 \\
\hline
\end{tabular}

$75.45,75$ for the median, 74.5 for the mode, and 2.2 for the standard deviation.

The writing scores of the low creative students in experimental class

The scores of the low creative students' writing in experimental class is depicted in table 6.

Table 6 . The scores of the low creative students' writing in experimental class

\begin{tabular}{lllllll}
\hline N & Mean & Mode & Median & $\begin{array}{l}\text { Standard } \\
\text { Deviation }\end{array}$ & Highest & Lowest \\
\hline 36 & 59.84 & 62 & 61 & 7.5 & 73.5 & 39.5
\end{tabular}

As revealed in table 6 , it is figured out that the average score is $59.84,61$ for the median, 62 for the mode, and 7.5 for the standard deviation.

\section{The writing scores of the high creative students in control class}

The scores of the high creative students' writing in control class can be seen in table 7.

Table 7 . The scores of the high creative students' writing in control class

\begin{tabular}{lllllll}
\hline N & Mean & Mode & Median & $\begin{array}{l}\text { Standard } \\
\text { Deviation }\end{array}$ & Highest & Lowest \\
\hline 36 & 58.01 & 65.5 & 59.5 & 9.5 & 72.5 & 35 \\
\hline
\end{tabular}

As depicted in table 7 , it is shown that the average score is $58.01,59.5$ for the median, 65.5 for the mode, and 9.5 for the standard deviation.

\section{The writing scores of the low creative students in control class}

The scores of the low creative students' writing in control class is depicted in table 8. 
Table 8. The scores of the low creative students' writing in control class

\begin{tabular}{lllllll} 
N & Mean & Mode & Median & $\begin{array}{l}\text { Standard } \\
\text { Deviation }\end{array}$ & Highest & Lowest \\
\hline 36 & 59.04 & 62.5 & 61.5 & 9.7 & 78 & 34.5 \\
\hline
\end{tabular}

As shown in the table 8 , it is figured out that the average score is 59.04 , 61.5 for the median, 62.5 for the mode, and 9.7 for the standard deviation.

\section{Data analysis}

Before the inferential analysis was employed to analyze the data, the authors had to ensure that the samples were distributed normally and homogeneously. The results and the calculations of normality and homogeneity test could be seen as follows:

\section{Normality test}

Utilizing normality test is intended to find out if a population is normal or not. In this research, the normality test was applied to the writing scores of experimental and control classes in accordance with the creativity level. Afterwards, Lilliefors test was employed to know the normality of learning models and creativity level. Based on the result of normality test, it is revealed that $\mathrm{L}_{\mathrm{o}}$ of the scores of the students' writing in both experimental and control class are 0.0922 and 0.1020 respectively which is lower than $L_{\text {table }}(0.1044)$. The $\mathrm{L}_{\circ}$ of the writing scores of the high creative students $(0.1036)$ and the low creative ones (0.140) in those two classes is less than $\mathrm{L}_{\text {table }}(0.1044)$. Besides, the $L_{o}$ of the writing scores of the high $(0.1436)$ and low creative students $(0.1374)$ in the experimental class is lower than the $\mathrm{L}_{\text {table }}(0.1443)$. In the control class, the $\mathrm{L}_{o}$ of the writing scores of the high $(0.1226)$ and low creative students $(0.1404)$ is less than the $\mathrm{L}_{\text {table }}(0.1443)$. Since all the obtained $\mathrm{L}_{0}$ is

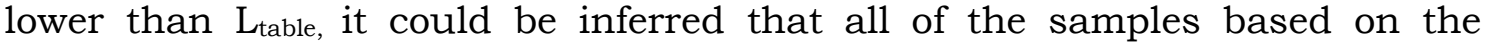
learning models and creativity levels were in normal distribution.

\section{Homogeneity test}

Employing homogeneity test is aimed to know whether all the data are homogeneous or not. This is necessary that all the data be homogeneous before conducting the further analysis (ANOVA). It is stated that the data are homogeneous if $\chi_{0}^{2}$ is lower than $\chi_{t}^{2}$ at the level of significance $a=0.05$. Based on the result of homogeneity test, the score of $\chi_{0}^{2}=4.751$. Due to $\chi_{0}^{2}$ $(4.751)$ is lower than $\chi_{t}^{2} 0.95(3)(7.39)$ or $\chi_{0}^{2}<\chi_{t}^{2}(4.751<7.39)$, we could conclude that the date are homogeneous.

\section{Testing hypotheses}

In testing hypotheses, the Multifactor Analysis Variance (ANOVA) 2 X 2 is used to find out if there are effects of independent and moderator variable upon the dependent variable. The tests are also intended to reveal if there is an interaction among those variables. ANOVA is done after the result of normality and homogeneity test are calculated and fulfilled. In ANOVA, Ho is rejected if $F_{o}$ is higher than $F_{t}\left(F_{o}>F_{t}\right)$ which means that there is significant difference. Furthermore, the analysis is continued to know the difference between the 
Krisbiantoro, B., \& Pujiani, T. (2021). The effectiveness of MALL and flipped classroom in teaching writing to the eleventh graders of SMA in Banyumas. EduLite: Journal of English Education, Literature, and Culture, 6 (1), 86-104. http://dx.doi.org/10.30659/e.6.1.86-104

cells by using Tukey test. To know which group is better, the mean scores of the groups are compared. The summary of ANOVA $2 \times 2$ can be seen in table 9.

Table 9. The mean scores summary

\begin{tabular}{llll}
\hline \multirow{2}{*}{ CREATIVITY (B) } & \multicolumn{2}{l}{ TEACHING METHODS (A) } & \multirow{2}{*}{$\begin{array}{l}\text { Flipped } \\
\left(\mathrm{A}_{2}\right)\end{array}$} \\
\cline { 2 - 3 } & $\operatorname{MALL}\left(\mathrm{A}_{1}\right)$ & classroom & Total \\
\hline High Creativity $\left(\mathrm{B}_{1}\right)$ & $\bar{X} \quad \mathrm{~A}_{1} \mathrm{~B}_{1}=75.46$ & $\bar{X} \mathrm{~A}_{2} \mathrm{~B}_{1}=58.01$ & $\bar{X}=66.73$ \\
\hline Low Creativity $\left(\mathrm{B}_{2}\right)$ & $\bar{X} \mathrm{~A}_{1} \mathrm{~B}_{2}=59.85$ & $\bar{X} \mathrm{~A}_{2} \mathrm{~B}_{2}=59.04$ & $\bar{X}=59.44$ \\
\hline Total & $\bar{X}=67.65$ & $\bar{X}=58.52$ & $\bar{X}=63.09$ \\
\hline
\end{tabular}

Table 10 . The summary result of 2 X 2 ANOVA

\begin{tabular}{|c|c|c|c|c|c|}
\hline Sources of Variance & SS & $\mathrm{df}$ & MS & $\mathrm{F}_{\mathrm{o}}$ & $F_{t(.05)}$ \\
\hline $\begin{array}{l}\text { Between columns } \\
\text { (Teaching Methods) }\end{array}$ & 2997.56 & 1 & 2997.56 & 49 & 3.97 \\
\hline $\begin{array}{ll}\text { Between } & \text { rows } \\
\text { (Creativity) } & \\
\end{array}$ & 1914.06 & 1 & 1914.06 & 31 & \\
\hline $\begin{array}{l}\text { Columns by rows } \\
\text { (Interaction) }\end{array}$ & 2491.67 & 1 & 2491.67 & 41 & \\
\hline Between groups & 7403.29 & 3 & 2467.76 & - & \\
\hline Within groups & 8589.02 & 140 & 61.35 & - & \\
\hline Total & 23395.62 & 143 & & & \\
\hline
\end{tabular}

Based on the result of ANOVA, it is inferred that $\mathrm{F}_{\mathrm{o}}$ between columns, the comparative analysis between the effect of teaching methods using MALL and flipped classroom, shows that $F_{o}$ is $49 . F_{o}(49)$ is higher than $F_{t(.05)}$ (3.97). It implies that Ho is rejected and there is a significant difference between MALL and Flipped classroom to teach writing. The average score of the learners in experimental group (67.65) is bigger than that of those in control group (58.52). In other words, in teaching writing MALL is more effective than Flipped classroom.

The $F_{o}$ of creativity (31) is higher than $F_{t}$ (3.97) meaning that $H_{o}$ is rejected and there was a substantial difference between writing score of the high creative students and the low creative ones. In addition, the average score of the high creative learners (66.73) is bigger than that of those with low creativity (59.44). As a result, the high creative students possess a better writing skill than those whose creativity is low.

The score of $F_{o}$ columns by rows (interaction) is 41 and the score of $F_{t}$ at the level of significance $a=0.05$ is 3.97. Because $F_{o}>F_{t .05)}$ or $F_{o}(41)$ is higher than $F_{t}$ (3.97), there is an interaction effect between two variables, learning models and students' creativity on the students' writing competence. In other words, it can be said that the effects of learning models on students' writing competence depend on the students' degree of creativity.

Furthermore, in order to find out whether the mean difference between the cells is significant or not, Tukey's HSD test was used. The result of analysis of the data using Tukey's HSD test is described in table 11.

Table 11. The result of Tukey's HSD test

\begin{tabular}{lllllll}
\hline No & Data & Sample & $\mathrm{q}_{\mathrm{o}}$ & $\mathrm{q}_{\mathrm{t}}$ & $\mathrm{A}$ & Status \\
\hline 1. & $\mathrm{A}_{1}$ and $\mathrm{A}_{2}$ & 72 & 9.89 & 2.81 & 0.05 & Significant \\
\hline 2. & $\mathrm{B}_{1}$ and $\mathrm{B}_{2}$ & 72 & 7.89 & 2.81 & 0.05 & Significant \\
\hline 3. & $\mathrm{A}_{1} \mathrm{~B}_{1}$ and $\mathrm{A}_{2} \mathrm{~B}_{1}$ & 36 & 13.36 & 2.87 & 0.05 & Significant \\
\hline 4. & $\mathrm{A}_{1} \mathrm{~B}_{2}$ and $\mathrm{A}_{2} \mathrm{~B}_{2}$ & 36 & 0.4 & 2.87 & 0.05 & Not Significant \\
\hline
\end{tabular}


From the table 11 , it can be seen that the value of $q_{0}$ between columns is 9.89 and the value of $q_{t}$ of Tukey's table at the level of significance $a=0.05$ is 2.81 meaning that that there is a substantial difference between MALL and Flipped classroom. The score of $\mathrm{q}_{\mathrm{o}}$ between rows (7.89) is higher than $\mathrm{q}_{\mathrm{t}}(.05)$ (2.81) which means that the difference on the students' writing score between high creative students and low creative ones is significant. The score of $\mathrm{q}_{\mathrm{o}}$ between cells A1B1 and A2B1 is 13.36 and the score of $\mathrm{q}_{t}$ of Tukey's table at the level of significance $a=0.05$ is 2.87 meaning that there is a significant difference between MALL and Flipped classroom to teach writing to high creative students. The score of qo between cells A1B2 and A2B2 (0.4) is lower than $\mathrm{q}_{\mathrm{t}}(.05)$ (2.86) meaning that there is not any significant difference in employing MALL and Flipped classroom to teach writing for the low creative students.

\section{Discussions of the results}

Teacher-centered English learning is one of the sources of student learning, of course in modern times it cannot advance education completely and quickly. Advances in technology do not mean eliminating the role of teachers in the classroom, but must help teachers to create a comfortable learning atmosphere. The use of MALL in the form of an application and a social medium in learning (Nearpod and Line in this case) made students and teachers more relaxed when discussing and practicing the material provided (i.e. writing analytical exposition text).

MALL can encourage teachers to be more creative in providing material and exercises in the form of video, audio, audiovisual and written. Students can also easily send their work or assignments in the form of direct comments. Through the Line group that was created, discussions were not only between teachers and students, but also between students and other students. Through this medium the students can overcome shame, negativity, and an unwillingness to express their feelings.

MALL motivates the students to formulate their thoughts and then jot them down well and properly. The teacher uses MALL to teach the students to write well. Here the role of the teacher is not only as a tutor but also as a facilitator. It deals a lot with the teacher's ability to facilitate group discussion in the Line group, allow a conducive atmosphere that learners can mingle with the question and answer session, give corrections and check the advancement of the groups. Then they start to convey their thoughts and solutions in a text.

MALL enables the students to experience greater interaction and collaboration. In this study, the students who were taught writing an analytical exposition text using MALL could have a writing collaboration with the other students. The findings provided evidence that MALL considers group work as a determining factor for the better performance of the participants in the experimental group. The findings are in line with a research by Gharehblagh \& Nasri (2020) which stated that the students who were exposed to mobile use achieved a better interaction and they could write a text cooperatively and collaboratively. Another research conducted by Zaki \& Yunus (2015) yielded that mobile learning could be integrated with academic writing by utilizing it with several writing approaches which complements the 
Krisbiantoro, B., \& Pujiani, T. (2021). The effectiveness of MALL and flipped classroom

pedagogical advantages in mobile devices. It was also stated that the potential of mobile learning in teaching ESL academic writing is high.

On the contrary, flipped classroom allows the learners to view the lesson video shared in Google Classroom and discuss about it. The day after they practice more and more in the class. Because the students were having an SFH (study from home) because of COVID-19 Pandemic, the in-class activities were carried out through Google Meet.

Learners will not have a productive and effective work if Flipped classroom is used to teach writing. It occurs because the students who have just known this method requires adaptation because of learning autonomously at home. Consequently, they are not ready with the active learning in the classroom. Moreover, the students' interest and motivation to learn writing at home before going to the classroom rely on the teachers when choosing and creating the learning videos and or another material such as a reading text or a sample of a written text. The homework (text and video) must be adjusted appropriately and cautiously so as to prepare the learners to join the learning. The teacher also cannot ensure that all students have watched the video at their houses. It happens because not all students have a sufficient internet packet data and or their houses are in a remote area so that it is hard to get an internet access to download the video. Consequently, when they come to the classroom, they will ask their teacher to watch the video together and it is time-consuming. The thing is that the students should have watched it at home.

Moreover, by using flipped classroom the teacher will give a model of text to the students during the in-class activity. The students will always imitate the model of text given by their teacher so they are not capable of writing a text without looking at the model of the text. Furthermore, flipped classroom makes the teacher limit the students' creative ideas and thoughts because the teacher often guides the students without considering their creative and innovative ideas. This guidance occurs during the in-class activities where the students interact with the others. Besides, flipped classroom causes the students to learn how to write the text themselves beforehand and it really requires the students' motivation and preferences. The learners were not encouraged to learn the instructions and materials by themselves at home because they lack of motivation and time to learn and understand the materials as well as the limitation of the facilities regarding with the internet connection and the data packet besides the materials which are uninteresting for them. They preferred to have a direct instruction given by the teachers from the front of the class. Even the teachers could not monitor the students' independent study and the insufficiency of preparation for the activities in the classroom could influence the students' motivation, engagement and creativity. These findings concur with several other studies reporting negative attitudes towards the flipped classroom (Taylor, 2015; Alghasab, 2020; (Betul \& Demirer, 2016; Du et al., 2014).

Another finding of this study is that the high creative students in both experimental and control classes possess a better writing skill than the low creative students. It is said that creativity is taken into account as an ability to form a new thing, contribute latest concepts, and make something totally different in problem solving. Creative students are capable of checking out 
EduLite Journal of English Education, Literature, and Culture

Vol. 6, No. 1, February 2021, pp. 86-104

E-ISSN: 2528-4479, P-ISSN: 2477-5304

http://jurnal.unissula.ac.id/index.php/edulite DOI: http://dx.doi.org/10.30659/e.6.1.86-104

ways in which in understanding material and doing examination successfully, changing into a drag problem solver in an exceedingly team, manufacturing new ideas and doing originative actions, and continuously own a breakthrough in performing their creative thinking. Creative students can think on the far side what they see, read, and listen. In an exceedingly learning process, the high creative students are going to be ready to return up with surprising ideas higher than the low creative students. On the other way around, the students who have low creative thinking tend to be passive. They do not seem to be continuously unintelligent. They solely limit their way of thinking to explore their idea, bravery, diligence, and seriousness as they are not assured enough to share. Moreover, they are unable to return up with their own recent concepts and opinions once learning. They lack of ideas and often surrender once they need to do something.

This study also revealed that there was an interaction effect between MALL and Flipped classroom and creativity on the students' skill of writing. MALL requires the students to interact actively, think critically, and solve problem quickly. All of the indicators of writing like grammar, content, vocabulary, organization, and mechanics can be developed using MALL. MALL asks the learners to creatively express their feeling, ideas, opinions, and thoughts. The teaching processes of MALL allow the students to elicit their prior knowledge on the given topics, ask them to work collaboratively to write the outline of their text writing, ask them to find information and share with other students, give comment and feedback to the students' writing, and finally write analytical exposition text. Kukulska-Hulme \& Shield (2007) stated that it was appropriate to apply mobile learning so as to encourage social interaction and cooperative learning. Burston (2015) also stated that there was a substantial contribution of MALL to enhance the learning of language as well as to promote collaborative interactions.

It is undeniable that there are two types of students viewed from the way of their thinking; the high creative students and the low creative ones. The high creative students will easily develop ideas. They can write a text fluently without having any difficulty. Besides, the high creativity students are capable of exploring and expanding their competence, skills, and talents. Their curiosity to always try something new is very high. Even, they like to think of something in many different ways from what the other people think. Boden (2009) defined creativity as an ability to elicit concepts that are current, surprising, and valuable. It is highly likely for high creative students to quickly and easily convey their thoughts in a text.

The low creative students are capable of demonstrating incredible activities in their text. Some teachers prefer teaching writing analytical exposition to the high creative students. They can teach them easily without facing serious problems such as the students' lack of vocabularies and the students' problem solving way. The students with high creativity can be taught to write an analytical exposition text by various teaching methods especially MALL. They listen to the teacher's presentation, learn and analyze the text models, solve the problems (cases) given by the teachers, practice to compose a text draft until eventually create a final composition.

In this research, for low creative learners in both experimental and control classes, MALL as well as flipped classroom do not differ significantly to 
Krisbiantoro, B., \& Pujiani, T. (2021). The effectiveness of MALL and flipped classroom in teaching writing to the eleventh graders of SMA in Banyumas. EduLite: Journal of English Education, Literature, and Culture, 6 (1), 86-104. http://dx.doi.org/10.30659/e.6.1.86-104

teach writing. The following description explains further what makes MALL and Flipped classroom take equal level for students with low creativity. The low creative students are shy, have low self-confidence and competency to present new ideas in completing the project. They are unable to compose ideas better than those who have high creativity since their creativity is low. The students who have low creativity are often afraid and also cannot explore their ideas in writing text. Some of them are unable to create a good text. They often feel discouraged to learn something new because what comes in their mind will be absorbed and taken directly. They never want to try to develop the new things to be better things for them and other people. They are so passive to think or produce numbers of ideas quickly. Therefore, there is no significant difference between MALL and Flipped classroom in teaching writing for the learners with low creativity. It means that MALL and Flipped classroom are equal to teach the low creative students.

\section{CONCLUSION}

Having seen the result of the hypotheses testing, the researchers conclude some findings: (1) In teaching writing, MALL is more effective than Flipped classroom; (2) The high creative students possess a better writing skill than the low creative students; and (3) An interaction effect occurs between MALL and flipped classroom and creativity on the students' skill of writing. This can be referred from the results of this research that for high creative learners, MALL is more effective than Flipped classroom. Meanwhile, for low creative students, flipped classroom is as effective as MALL.

Thus, MALL is an efficacious instruction way to teach writing skills. The level of the learners' creativity determines the effectiveness of the teaching methods. It is advised that other researchers apply mobile learning-assisted activities by which the students can improve their writing skills. This research could own valuable significance for educators and students since teaching and learning how to write an English text using MALL can enhance the teachers and students' flexibility, creativity and active interaction as well as feedback from both the students and the teachers. Furthermore, the findings can provide fruitful information and knowledge to help improving the students' writing skill. The students can also utilize their mobile devices to have an online learning and to be a form of self-study.

\section{ACKNOWLEDGEMENTS}

The researchers vastly feel gratitude to the Research and Technology and Higher Education Ministry for supporting us the funding and chance to undertake this research (Novice Lecturer Research/PDP). Besides, we want to thank all of the learners who have taken a part in this research. 
Edulite Journal of English Education, Literature, and Culture

Vol. 6, No. 1, February 2021, pp. 86-104

E-ISSN: 2528-4479, P-ISSN: 2477-5304 http://jurnal.unissula.ac.id/index.php/edulite DOI: http://dx.doi.org/10.30659/e.6.1.86-104

\section{REFERENCES}

Abdelrahman, L. A. M., Dewitt, D., Alias, N., \& Abdul Rahman, M. N. (2017). Flipped learning for ESL writing in a Sudanese school. Turkish Online Journal of Educational Technology, 2017 (November Special Issue IETC), 324-330. https://eric.ed.gov/?id=EJ1152605.

Alemi, M., Sarab, M. R. A., \& Lari, Z. (2012). Successful learning of academic word list via MALL: Mobile assisted language learning. International Education Studies, 5(6), 99-109. https://doi.org/10.5539/ies.v5n6p99.

Alghasab, M. B. (2020). Flipping the writing classroom: Focusing on the pedagogical benefits and EFL learners' perceptions. English Language Teaching, 13(4), 28. https://doi.org/10.5539/elt.v13n4p28.

Alotumi, M. (2019). EFL learning beyond the wall with MALL. 138-160. https://doi.org/10.4018/978-1-7998-2116-8.ch007.

Anwar, C. (2017). Flipped classroom in teaching vocabulary. The $2^{\text {nd }}$ TEYLIN International Conference Proceedings, Kudus: April 2017. 109-115. http://eprints.umk.ac.id.

Baleghizadeh, S., \& Oladrostam, E. (2010). The effect of Mobile Assisted Language Learning ( MALL ) on grammatical accuracy of EFL students. MEXTESOL Journal, $34(2)$ $1-10$. http://www.mextesol.net/journal/index.php?page=journal\&id_article=50.

Betül, A., \& Demirer, V. (2016). Flipping the drawbacks of flipped classroom: effective tools and reccomendations. Journal of Educational and Instructional Studies in the World, 6(1), 2146-7463.

Boden, M. (2009). Creativity: How does it work? Philosophy of history and culture, 28(December), 237-250.

Brame, C. J. (2012). Flipping the classroom inverted classroom. Vanderbilt University, 13-15. http://www.cirtl.net/node/7788.

Burston, J. (2013). Mobile-assisted language learning: A selected annotated bibliography of implementation studies 1994-2012. Language, Learning and Technology, 17(3), 157-225. https://www.learntechlib.org/p/154092/.

Burston, J. (2014). MALL: The pedagogical challenges. Computer Assisted Language Learning, 27(4), 344-357. https://doi.org/10.1080/09588221.2014.914539.

Burston, J. (2015). Twenty years of MALL project implementation: A meta-analysis of learning outcomes. ReCALL, 27(1), 4-20. https://doi.org/10.1017/S0958344014000159.

Çakmak, F. (2019). Mobile learning and mobile assisted. Language and Technology, 1(1), 30-48. https://dergipark.org.tr/en/pub/lantec/issue/42816/517381.

Cheng, S. C., Hwang, W. Y., Wu, S. Y., Shadiev, R., \& Xie, C. H. (2010). A mobile device and online system with contextual familiarity and its effects on english learning on campus. Educational Technology and Society, 13(3), 93-109. https://doi.org/10.1109/DIGITEL.2010.57.

Du, S., Fu, Z., Wang, Y., Stonebraker, B. I. R., Robertshaw, M. B., Kirkwood, H. P., \& Dugan, M. (2014). 43295343.Pdf. International Conference on Economic Management and Trade Cooperation, (Emtc), 17-20. Retrieved from file:// /C:/Users/Dylan Ryan/Downloads/11721.pdf

Egbert, J., Herman, D., \& Lee, H. (2015). Flipped instruction in English language 
Krisbiantoro, B., \& Pujiani, T. (2021). The effectiveness of MALL and flipped classroom in teaching writing to the eleventh graders of SMA in Banyumas. EduLite: Journal of English Education, Literature, and Culture, 6 (1), 86-104. http://dx.doi.org/10.30659/e.6.1.86-104

teacher education: A Design-based study in a complex, open-ended learning environment. Tesl-Ej, 19(2), 1-23. https://eric.ed.gov/?id=EJ1074707.

Firipis, A., Chandrasekaran, S., \& Joordens, M. (2018). Influence of Critical Thinking on Creativity When Using Mobile Devices for Learning. Asian Education Studies, 3(2), 40. https://doi.org/10.20849/aes.v3i2.366.

Gangaiamaran, R., \& Pasupathi, M. (2017). Review on use of mobile apps for language learning. International Journal of Applied Engineering Research, 12(21), 1124211251. http://www.ripublication.com/ijaer17/ijaerv12n21_102.pdf.

Geddes, S. J. (2004) Mobile learning in the 21st century: benefit to learners. Retrieved http://knowledgetree.flexiblelearning.net.au/edition06/download/geddes.

Gharehblagh, N. M., \& Nasri, N. (2020). Developing EFL elementary learners' writing skills through mobile-assisted language learning (MALL). Teaching English with Technology, 20(1), 104-121. https://www.ceeol.com/search/articledetail?id=826646.

Gonulal, T. (2019). The use of instagram as a mobile-assisted language learning tool. Contemporary Educational Technology, 10(3), 309-323. https://doi.org/10.30935/cet.590108.

Hamdan, N., McKnight, P., McKnight, K., \& Arfstrom, K. M. (2013). A Review of Flipped Learning. (c), 20.

Jarvis, W., \& Halvorson, W. (2014). A Large Class Engagement (LCE) Model Based on Service-Dominant Logic (SDL) and Flipped classrooms. Education Research and Perspectives, $\quad 41(1)$, https://researchrepository.murdoch.edu.au/id/eprint/54358/.

$1-24$.

Kalati, E. A. (2013). Ezat Amirbakzadeh Kalati MA TESOL 2013 United Kingdom Bio statement: 1 . BA TEFL, ranked 1st. Azad University of Mashhad, Foreign Language 2 . MA TESOL, University of Bath, Department of Education . United Kingdom Mobile Assisted Language Learning A. Ma Tesol 2013, (January), 1-22.

Khubyari, L., \& Narafshan, M. H. (2016). AsStudy on the impact of MALL (Mobile Assisted Language Learning) on EFL learners' reading comprehension. International Journal of English Language Teaching, 4(2), 58-69. http://www.eajournals.org.

Kim, D., Ruecker, D., \& Kim, D.-J. (2018). Mobile Assisted Language Learning Experiences. Computer-Assisted Language Learning, (February), 1059-1077. https://doi.org/10.4018/978-1-5225-7663-1.ch050.

Krisbiantoro, B., Pujiani, T. (2019). Flipped learning for EFL writing in an Indonesian. E-Proceedings of International Conference on Innovation in Education: Opportunities and Challenges in Southeast Asia, Semarang: 29-30 October 2019. 232-254. http:// proceedings.aecon.ump.ac.id.

Kukulska-Hulme, A., \& Shield, L. (2007). An overview of Mobile Assisted Language Learning: Can mobile devices support collaborative practice in speaking and listening. EuroCALL 2007, 1-20. http://sites.google.com/site/vsportal2007/Kukulska_Hulme_and_Shield_2007. pdf.

Li, J., \& Cummins, J. (2019). Effect of using texting on vocabulary instruction for English learners. Language Learning and Technology, 23(2), 43-64. http://hdl.handle.net/10125/44682.

Mok, H. N. (2014). Teaching tip: The flipped classroom. Journal of Information Systems 
Edulite Journal of English Education, Literature, and Culture

Vol. 6, No. 1, February 2021, pp. 86-104

E-ISSN: 2528-4479, P-ISSN: 2477-5304

http://jurnal.unissula.ac.id/index.php/edulite DOI: http://dx.doi.org/10.30659/e.6.1.86-104

Education, 25(1), 7-11. https://www.gale.com/subject-matter.

Munandar, U. (1988a). Kreativitas sepanjang masa. Balai Pustaka.

Rahamat, R. (2019). Designing mobile learning: Empirical journey to reality in Malaysian secondary school context. EduLite: Journal of English Education, Literature and Culture, 4(1), 13. https://doi.org/10.30659/e.4.1.13-24

Rodríguez, G., Díez, J., Pérez, N., Baños, J. E., \& Carrió, M. (2019). Flipped classroom: Fostering creative skills in undergraduate students of health sciences. Thinking Skills and Creativity, 100575. https://doi.org/10.1016/j.tsc.2019.100575.

Roehl, A., Reddy, S. L., \& Shannon, G. J. (2013). The flipped classroom: An opportunity to engage millennial students through active learning strategies. Journal of Family \& Consumer Sciences, 105(2), 44-49. https://www.questia.com/library/journal/1P3-3048625171/the-flippedclassroom-an-opportunity-to-engage-millennial.

Rohandi, M., Husain, N., \& Bay, I. W. (2017). Mobile-Assisted Language Learning Application for English Intensive Course. (January). https://doi.org/10.2991/ictvt-17.2017.11.

Shadiev, R., Liu, T., \& Hwang, W. Y. (2020). Review of research on mobile-assisted language learning in familiar, authentic environments. British Journal of Educational Technology, 51(3), 709-720. https://doi.org/10.1111/bjet.12839.

Shamsi, A. F., Altaha, S., \& Gilanlioglu, I. (2019). The Role of M-Learning in Decreasing Speaking Anxiety for EFL Learners. International Journal of Linguistics, Literature and Translation (IJLLT), 2(1), 277-282. https://doi.org/10.32996/ijllt.2019.2.1.34.

Shi, Z., Luo, G., \& He, L. (2017). International journal of emerging technologies in learning. International Journal of Emerging Technologies in Learning (IJET), 12(02), 16-26. $\quad$ https://online-journals.org/index.php/ijet/article/view/6681/4281.

Shimamoto, D. (2012). Implementing a flipped classroom: An instructional module. TCC Conference, $9 . \quad$ Retrieved from http://scholarspace.manoa.hawaii.edu/handle/10125/22527.

Smith, J. P. (2015). The efficacy of a flipped learning classroom. (Published Dissertation). McKendree University. ProQuest LLC.

Sprinthall, R. C. (2014). Basic Statistical Analysis. Ninth ed. Pearson Education Limited.

Taylor, A. (2015). Flipping great or flipping useless? a review of the flipped classroom experiment at Coventry University London Campus. Journal of Pedagogic Development, 5(3), 57-65.

Tirtasanjaya, L. L., Wen, T. C., et al. (2012). Assessing the Effectiveness of Flipped classroom Pedagogy in Promoting Students' Learning Experience. NYGH Research Journal.

Vemula, R. K. (2018). Mobile Assisted Language Learning. http://researchgate.net/publication/338966307.

Wahyuni, S., Fitriati, S. W., \& Maharani, J. C. (2019). Use of Mobile Learning Applications to Support Paperless Classroom Pedagogy. (Ceclace), 51-54. http://proceeding.unnes.ac.id. 
Krisbiantoro, B., \& Pujiani, T. (2021). The effectiveness of MALL and flipped classroom in teaching writing to the eleventh graders of SMA in Banyumas. EduLite: Journal of English Education, Literature, and Culture, 6 (1), 86-104. http://dx.doi.org/10.30659/e.6.1.86-104

Zaki, A. A., \& Yunus, M. M. (2015). Potential of mobile learning in teaching of ESL academic writing. English Language Teaching, 8(6), 11-19. https://doi.org/10.5539/elt.v8n6p11.

Conflict of Interest Statement: The authors declare that the research was conducted in the absence of any commercial or financial relationships that could be construed as a potential conflict of interest.

Copyright (C) 2021 Krisbiantoro and Pujiani. This is an open-access article distributed under the terms of the Creative Commons Attribution License (CC BY). The use, distribution or reproduction in other forums is permitted, provided the original author(s) and the copyright owner(s) are credited and that the original publication in this journal is cited, in accordance with accepted academic practice. No use, distribution or reproduction is permitted which does not comply with these terms. 